\title{
INFLUENCE OF THE OZONATED WATER APPLICATION ON THE OCCURRENCE OF SOME PESTS AND DISEASES IN SPRING WHEAT CROP
}

\begin{abstract}
Sonata KAZLAUSKAITÉ, Institute of Biology and Plant Biotechnology, Agriculture Academy, Vytautas Magnus University. K. Donelaičio str. 58, LT-44248, Kaunas, Lithuania, sonata.kazlauskaite@ vdu.lt (corresponding author).

Vidmantas SPRUOGIS, Institute of Environment and Ecology, Agriculture Academy, Vytautas Magnus University. K. Donelaičio str. 58, LT-44248, Kaunas, Lithuania, vidmantas.spruogis@ vdu.lt

Anželika DAUTARTE், Institute of Environment and Ecology, Agriculture Academy, Vytautas Magnus University. K. Donelaičio str. 58, LT-44248, Kaunas, Lithuania, anzelika.dautarte@vdu.lt

Povilas MULERČIKAS, Institute of Biology and Plant Biotechnology, Agriculture Academy, Vytautas Magnus University. K. Donelaičio str. 58, LT-44248, Kaunas, Lithuania, povilas.mulercikas@ vdu.lt

Aurimas KRASAUSKAS, Institute of Biology and Plant Biotechnology, Agriculture Academy, Vytautas Magnus University. K. Donelaičio str. 58, LT-44248, Kaunas, Lithuania, aurimas.krasauskas@ vdu.lt

Kimete Lluga RIZANI, University of Prishtina, Rr. "George Bush", Nr.31, 10000 Prishtinë, Republika e Kosovës, kimete.lluga@uni-pr.edu Elena SURVILIENE், Kaunas College of Forestry and Environmental Engineering, Liepų str. 1, Girionys, LT 53101 Kaunas distr., Lithuania, esurviliene@yahoo.com

Investigations were carried out in the production fields of agricultural company Linas in Ringaudai eldership, Kaunas district. Spring wheat variety 'Koksa' was grown on non-damp, light loamy soil with a mobile phosphorus content of $173 \mathrm{mg} \mathrm{kg}^{-1}$ and a potassium content of $139 \mathrm{mg} \mathrm{kg}^{-1}$. Soil acidity - pH 6.9-7.0. The ozonator was attached on the trailing sprayer JARMET. During the studies, the concentration of ozone-saturated water and the spray rate were determined so as not to damage the crop, pollute the environment, or harm humans or animals. The speed of the sprayer was $6 \mathrm{~km} \mathrm{~h}^{-1}$. The application was performed 2 or 4 times. It was determined that treatment of spring wheat with ozonated water, although not always statistically significantly, however, reduced the occurrence of powdery mildew (Blumeria graminis), brown rust (Puccinia recondita), and inhibited the spread of aphids. A tendency for tan spot (Pyrenophora tritici repentis) and thrips decrease in the crop was observed. The aim of the study was to determine the effect of ozonated water application on the spread of spring wheat pests and leaf diseases.
\end{abstract}

Keywords: ozonated water, non-chemical plant protection, powdery mildew.

\section{INTRODUCTION}

In the Chemical Encyclopedia (2015), ozone is described as an allotropic type of the oxygen. It is a blue-coloured poisonous gas which is soluble in water and has a pungent irritating odour. Ozone is a strong oxidant and an effective disinfectant agent (Guzel-Seydim et al., 2004; Glowacz et al., 2015; Glowacz, Rees, 2016; Han et al., 2017; Hua-Li et al., 2018). Usually it is toxic to plants, however, at certain concentrations can be successfully used to provoke plant defences against environmental stressors that can be a variety of pathogens (Violini, 1995; Pazarlar et al., 2017, Han et al., 2017).

There is a serious lack of scientific publications on the ozone application for plant protection purposes. The most research has been carried out concerning ozone application for postharvest, storage and during transportation agricultural production protection. Ozone is also of interest to climate change researchers, who sometimes focus their experiments on the effects of ozone on the spread of harmful organisms. The effect of ozone on aphids in pine seedlings under conditions of increased ozone concentration was investigated in Finland. The response of aphids to elevated ozone concentrations was variable and controversial in different study years. However, it was concluded that in most cases the effect of ozone on the increased susceptibility of seedlings to aphids was not statistically significant (Holopainen et al., 1997).

Hollingsworth and Armstrong (2005) described the results of research on the ozone application for ornamental plants protection against western thrips (Frankliniella occidentalis) and long-tailed mealybugs (Pseudococcus longispinus). Plants were treated with 0-3800 ppm ozone concentrations for 30-120 min. It was significantly more difficult to treat the long-tailed mealybugs with ozone. Treatment of the plants with ozone concentrations of about $200 \mathrm{ppm}$ for 30 minutes at $100 \% \mathrm{CO}_{2}$ concentration and $37.8^{\circ} \mathrm{C}$ temperature conditions resulted in $47.9 \%$ long-tailed mealybugs and $98.0 \%$ thrips mortality. Research has shown that ozone has a potential to be applied for ornamental plants treatment against some pests.

Ozone is reported as a potential substitute for methyl bromide against coffee berry borer (Hypothenemus hampei), coffee leaf rust (Hemileia vastatrix), bean thrips (Caliothrips fasciatus) (Hollingsworth, Armstrong, 2005).

Copyright (C) 2019 The Authors. Published by Vytautas Magnus University. This is an open-access article distributed under the terms of the Creative Commons Attribution License (CC BY 4.0), which permits unrestricted use, distribution, and reproduction in any medium, provided the original author and source are credited. 
Plant pathogens are necrotrophs and biotrophs. Necrotrophs release toxin molecules that damage the host's tissue cells with the purpose to absorb nutrients from the host-plant. Meanwhile, biotrophs use nutrients of the host-plant through certain morphological structures without damaging its tissue cells (Violini, 1995). Over the evolution, plants have developed a dual defence strategy against pathogens. Plant cells are able to secrete jasmonic acid for defence against necrotrophic pathogens. Salicylic acid is released to neutralize biotrophic pathogens. Ozone also induces the plant to accumulate salicylic acid, thereby triggering a defence response of the plant (Pazarlar et al., 2017). Since the colonization of the powdery mildew (Blumeria graminis) was stopped by treating the plants with ozone before and after infestation with the pathogen, the researchers concluded that the effect of ozone on physiological changes of the host-plant may be an effective means of reducing fungal spread (Violini, 1995). Interesting studies have been conducted in Turkey using ozone treatment against powdery mildew (Blumeria graminis DC Speer f. sp. tritici) in wheat. Two wheat varieties were selected: 'Pamukova' which is sensitive to powdery mildew and resistant variety 'Tahirova'. Both varieties were treated with ozone at $\mathrm{BBCH} 13$ stage, and the crops were artificially infected with the pathogen 72 hours later. The results of the study showed that ozone treatment was quite effective inhibiting the spread of powdery mildew in wheat, especially in susceptible wheat variety (Pazarlar et al., 2017). Glowacz et al. (2015) described the fungistatic effects of ozone on grey mould (Botrytis cinerea), white mould disease (Sclerotinia sclerotiorum) and other mould fungi in the juicy crop production. Melon treatment with $1.10 \mathrm{mg} \mathrm{l}^{-1}$ concentrations of ozone for $120 \mathrm{~min}$. resulted in a statistically significant reduction of dangerous fungus Fusarium sulphureum spread (Hua-Li et al., 2018). Although sources of evidence on the effectiveness of ozonated water are not abundant, the application of this measure for plant protection purposes seems to have some potential. and pests.

The aim of the study was to determine if the application of ozonated water has an impact on the spread of diseases

\section{METHODS}

Investigations were carried out in the production fields of agricultural company "Linas" in Ringaudai eldership, Kaunas district $\left(54^{\circ} 52^{\prime} 03.4^{\prime \prime} \mathrm{N}+23^{\circ} 46^{\prime} 21.7^{\prime \prime E}\right)$. Spring wheat variety 'Koksa' was grown in the field

The study was executed in 3 replicates according to the scheme:

1. Control (ozonated water was not applied).

2. Spraying with ozonated water at the beginning and at the end of the sprouting stage ( 2 time $\left.\mathrm{O}_{3}\right)$.

3. Spraying with ozonated water at the beginning and at the end of the sprouting stage; and again repeated spraying at the beginning and at the end of the stem growth stage (4 time $\mathrm{O}_{3}$ ).

4. Water spraying (4 time $\mathrm{H}_{2} \mathrm{O}$ ).

The size of the study field was $-672 \mathrm{~m}^{2}$ (24 m x $\left.28 \mathrm{~m}\right)$.

The soil was selected typical for central part of Lithuania - non-damp, light loam, free of weeds with a mobile phosphorus content of $173 \mathrm{mg} \mathrm{kg}^{-1}$ and a potassium content of $139 \mathrm{mg} \mathrm{kg}^{-1}$. Soil acidity - pH 6.9-7.0. Humus content according to the amounts of humus and humic acids was $2.55-2.56 \%$.

The ozonator was adapted for use in a mobile sprayer and installed on the trailing sprayer JARMET. Sprayer tank capacity was $2500 \mathrm{l}$, working width - $24 \mathrm{~m}$, pump UDOR $\left(2561 \mathrm{~min}^{-1}\right)$, adjustable beam height $(0.5-2.0 \mathrm{~m})$, slit and injector nozzles. Equipment for ozonated water production was installed at the company "Ozono centras". During the studies, the concentration of ozone-saturated water and the spray rate were determined so as not to damage the crop, pollute the environment, or harm humans or animals. The speed of the sprayer was $6 \mathrm{~km} \mathrm{~h}^{-1}$.

The yield was harvested with a special harvester "Wintersteger", which executes weighing of the grain, determines the moisture of the grain, and takes grain samples for chemical analysis as well.

Monitoring of diseased or pest infested plants was performed regularly. Five stems were inspected in ten places of the field, which means that 50 plants were examined in each replication. During the examination a degree of damage of the specific disease to each plant was assessed in accordance with the recommended scales for spring wheat. The number of healthy and damaged plants or stems, its percentage and disease intensity were determined.

Indicators of plant disease monitoring were calculated: percentage of plants, stems, leaves damaged by disease (P), disease intensity $(\mathrm{R})$.

Percentage of plants, stems, leaves damaged by disease $(\mathrm{P})$ was calculated (Žemès ūkio augalų kenkèjai, ligos ir jų apskaita, 2002):

$$
\mathrm{P}=(\mathrm{n} \cdot 100) / \mathrm{N}
$$

Here P - percentage of plants, stems, leaves damaged by disease; $n$ - number of damaged plants, stems, leaves; $\mathrm{N}$ - number of examined plants, stems, leaves.

Disease intensity (R) was calculated (Žemès ūkio augalų kenkèjai, ligos ir jų apskaita, 2002):

$$
\mathrm{R}=(\Sigma(\mathrm{n} \cdot \mathrm{b})) / \mathrm{N}
$$

Here R - disease intensity; $\Sigma\left(n^{*} \mathrm{~b}\right)$ - sum of the products of the number and value of damaged plants, stems, or leaves, damage of which have been evaluated by the same score or percentage; $\mathrm{N}$ - number of examined (or damaged) plants, stems, leaves. 
Indicators of pest-infested plants monitoring were calculated: the percentage of the pest-infested plants $(\mathrm{P})$ and the average number of pests on the infested plant $(\mathrm{K})$.

The percentage of the pest-infested plants (P) was calculated according to the formula (Žemès ūkio augalų kenkejjai, ligos ir jų apskaita, 2002):

$$
\mathrm{P}=(\mathrm{n} \cdot 100) / \mathrm{N}
$$

Here P - percentage of the pest-infested plants; $\mathrm{n}$ - number of pest-infested plants in the samples; $\mathrm{N}$ - number of examined plants.

The average number of pests on the infested plant $(\mathrm{K})$ was determined according to the formula (Žemès ūkio augalu kenkëjai, ligos ir jų apskaita, 2002):

$$
\mathrm{K}=\mathrm{m} / \mathrm{M}
$$

Here $\mathrm{K}$ - average number of pests on the infested plant; $\mathrm{m}$ - number of pests on the infested plant; $\mathrm{M}$ - number of infested plants.

The reliability of the obtained data was statistically evaluated using the statistical software ANOVA from the package "SELEKCIJA" according to Fisher's criterion.

\section{RESULTS}

Tan spot (Pyrenophora tritici repentis) usually affects the leaves of the plant, nevertheless, other above-ground parts of the plant may be damaged as well. The weather temperature of about $20-25^{\circ} \mathrm{C}$ and a relative humidity of more than $95 \%$ are recognised as optimal environmental conditions for the spread of the pathogen. The vegetation season 2018 was not favourable for the spread of tan spot disease considering prevailing meteorological conditions.

First symptoms of the disease were observed on 11th of May, however in only one of the all examined sites (Table 1). Any other plants with tan spot symptoms were not observed during subsequent monitoring.

Table 1. Percentage of plants damaged by tan spot (Pyrenophora tritici repentis) and disease intensity during crop monitoring in

\begin{tabular}{|c|c|c|c|c|c|}
\hline \multicolumn{6}{|c|}{ Percentage of plants damaged by disease $(P)$} \\
\hline \multirow{2}{*}{ Treatments } & \multicolumn{5}{|c|}{ Dates of collection of samples } \\
\hline & $11 / 05$ & $24 / 05$ & $31 / 05$ & 07/06 & $13 / 06$ \\
\hline Control & 0.00 & 0.00 & 0.00 & 14.00 & 30.00 \\
\hline 2 times $\mathrm{O}_{3}$ & 0.67 & 0.00 & 0.00 & - & - \\
\hline 4 times $\mathrm{O}_{3}$ & 0.00 & 0.00 & 0.00 & 26.00 & 17.33 \\
\hline $\mathrm{H}_{2} \mathrm{O}$ & 0.00 & 0.00 & 0.00 & 24.00 & 9.00 \\
\hline \multicolumn{6}{|c|}{ Disease intensity $(R)$} \\
\hline \multirow{2}{*}{ Treatments } & \multicolumn{5}{|c|}{ Dates of collection of samples } \\
\hline & $11 / 05$ & $24 / 05$ & $31 / 05$ & $07 / 06$ & $13 / 06$ \\
\hline Control & 0.00 & 0.00 & 0.00 & 0.25 & 0.67 \\
\hline 2 times $\mathrm{O}_{3}$ & 0.01 & 0.00 & 0.00 & - & - \\
\hline 4 times $\mathrm{O}_{3}$ & 0.00 & 0.00 & 0.00 & 0.50 & 0.39 \\
\hline $\mathrm{H}_{2} \mathrm{O}$ & 0.00 & 0.00 & 0.00 & 0.40 & 0.21 \\
\hline
\end{tabular}
different treatments of the experiment.

* - indicates a statistically significant difference, $\mathrm{P} \leq 0.05$

$26 \%$ of plants showed tan spot disease symptoms in spring wheat crop treated with ozonated water on 7 th of June. The intensity of the disease was low. Only single spots on the infected leaves of the plant were observed. Any statistically significant differences were not defined in the intensity of the disease comparing to the control.

According to the results of observations on 13th of June, $17.33 \%$ of plants were affected by tan spot in the spring wheat treated with ozonated water. Although ozone treated wheat was much less damaged by disease comparing to the control treatment, there was no statistically significant difference determined. The percentage of spring wheat damaged by tan spot and disease intensity were the lowest in water-treated wheat, however statistically insignificant.

Powdery mildew (Blumeria graminis) is a common and rapidly spreading disease in spring wheat crop. The vegetative season in 2018 was very favourable for the spread of powdery mildew in spring wheat crop, since the sporulation of $B$. graminis intensifies significantly when the weather is dry. The spread of powdery mildew is also influenced by the abundant use of nitrogenous fertilizers, the selection of susceptible varieties and over-dense crops.

The first symptoms of powdery mildew in spring wheat crop were detected on 17th of May (Table 2). The percentage of plants damaged by powdery mildew and disease intensity were very similar in all treatments of the experiment. Although according to the obtained results, the percentage of wheats damaged by powdery mildew and disease intensity were the lowest in ozonated water-treated spring wheat treatments, nevertheless statistically significant difference was not determined comparing to the control. Meanwhile, in water-treated sites, disease intensity was statistically higher than in the control.

One week later, on 24th of May, the percentage of plants damaged by powdery mildew increased in different treatments from $21.33 \%$ up to $34.66 \%$. The least percentage of spring wheat affected by disease was found in sites which were sprayed with ozonated water, however the obtained results did not differ significantly comparing to the control. Although disease intensity was still low at the time of monitoring for all treatments, nevertheless it was statistically significantly lower in wheat sprayed with ozonated water than in the control. 
During the monitoring carried out on 31st of May, ozonated water-treated sites contained the least percentage of wheats damaged by powdery mildew. Meanwhile, in the treatment where ozonated water was used twice, the percentage of plants damaged by the disease was determined statistically significantly lower comparing to the control. The intensity of powdery mildew was not high in all treatments. However, in treatments where ozonated water was used, the disease intensity was statistically significantly lower comparing to the control.

$95.33 \%$ of plants in the control treatment have been infected by powdery mildew during the monitoring on 7 th of June. The highest disease intensity was observed in control treatment. The lowest percentage of powdery mildew damaged plants and disease intensity was found in ozonated water-treated spring wheat sites, and both indicators were also statistically significantly different from the control.

Table 2. Percentage of plants damaged by powdery mildew (Blumeria graminis) and disease intensity during crop monitoring in different treatments of the experiment.

\begin{tabular}{|c|c|c|c|c|c|}
\hline \multicolumn{6}{|c|}{ Percentage of plants damaged by disease $(P)$} \\
\hline \multirow{2}{*}{ Treatments } & \multicolumn{5}{|c|}{ Dates of collection of samples } \\
\hline & $17 / 05$ & $24 / 05$ & $31 / 05$ & $07 / 06$ & $13 / 06$ \\
\hline Control & 40.67 & 75.33 & 30.67 & 95.33 & 67.33 \\
\hline 2 times $\mathrm{O}_{3}$ & 36.00 & 61.33 & $6.67 *$ & - & - \\
\hline 4 times $\mathrm{O}_{3}$ & 36.00 & 57.33 & 17.33 & $57.33^{*}$ & 42.00 \\
\hline $\mathrm{H}_{2} \mathrm{O}$ & 42.00 & 65.00 & 29.00 & $78.00 *$ & 73.00 \\
\hline \multicolumn{6}{|c|}{ Disease intensity $(R)$} \\
\hline \multirow{2}{*}{ Treatments } & \multicolumn{5}{|c|}{ Dates of collection of samples } \\
\hline & $17 / 05$ & $24 / 05$ & $31 / 05$ & $07 / 06$ & $13 / 06$ \\
\hline Control & 0.43 & 1.74 & 1.24 & 9.75 & 5.31 \\
\hline 2 times $\mathrm{O}_{3}$ & 0.36 & $0.83 *$ & $0.09^{*}$ & - & - \\
\hline 4 times $\mathrm{O}_{3}$ & 0.36 & $0.60 *$ & $0.33^{*}$ & $2.83 *$ & 1.13 \\
\hline $\mathrm{H}_{2} \mathrm{O}$ & $0.54 *$ & $1.31 *$ & 0.91 & $6.46^{*}$ & 5.68 \\
\hline
\end{tabular}

*-indicates a statistically significant difference, $\mathrm{P} \leq 0.05$

The lower percentage of powdery mildew damaged plants (compared with one week ago) were observed in all treatments of the experiment on 13th of June (Table 2). The lowest percentage of spring wheat infected by powdery mildew was detected in sites treated with ozonated water (42\%). However, the result did not differ significantly from the control. The lowest disease intensity was defined in spring wheat sprayed with ozonated water as well. Nevertheless, the difference from the control was not statistically significant.

Dry and warm weather are the most favourable conditions for aphids (Rhopalosiphum padi, Macrosiphum avenae) to propagate and spread. First aphids' specimens were detected during the monitoring of spring wheat crop on 24th of May (Table 3). $3.33 \%$ up to $10 \%$ of the plants in different treatments of the experiment were infested by aphids. The lowest percentage of plants infested by aphids was detected in spring wheat sites treated with ozonated water. However, the differences between treatments were statistically insignificant. At least 1 aphid specimen on average was found per infested plant in all treatments of the experiment. Nevertheless, any statistically significant differences were not defined comparing to the control.

Substantially more plants infested by pests were observed in the crop on 31st of May. $40 \%$ of spring wheat plants were infested by aphids in control. The lowest percentage of aphid infested plants was detected in ozonated water treated sites, and the obtained results were statistically significantly different from the control. The percentage of plants infested by pests was statistically significantly lower in water-treated spring wheat also. The average number of pests per infested plant was the lowest in wheat treated with ozonated water and reached 1.27 up to 1.63 specimens. However, in only one of two treatments, the result was statistically significantly different from the control.

Table 3. Percentage of plants infested by aphids and average number of pests per infested plant in different treatments of the experiment during the monitoring of spring wheat crop

\begin{tabular}{|c|c|c|c|c|}
\hline \multicolumn{5}{|c|}{ Percentage of plants infested by pests $(P)$} \\
\hline \multirow{2}{*}{ Treatments } & \multicolumn{4}{|c|}{ Dates of collection of samples } \\
\hline & $24 / 05$ & $31 / 05$ & $07 / 06$ & $13 / 06$ \\
\hline Control & 6.67 & 40.00 & 60.00 & 32.67 \\
\hline 2 times $\mathrm{O}_{3}$ & 4.00 & $14.67 *$ & - & - \\
\hline 4 times $\mathrm{O}_{3}$ & 3.33 & $16.67 *$ & $36.00 *$ & 24.00 \\
\hline $\mathrm{H}_{2} \mathrm{O}$ & 10.00 & $22.00^{*}$ & 44.00 & 40.00 \\
\hline \multicolumn{5}{|c|}{ Average number of pests per infested plant $(K)$} \\
\hline \multirow{2}{*}{ Treatments } & \multicolumn{4}{|c|}{ Dates of collection of samples } \\
\hline & $24 / 05$ & $31 / 05$ & $07 / 06$ & $13 / 06$ \\
\hline Control & 1.07 & 2.24 & 3.41 & 8.94 \\
\hline 2 times $\mathrm{O}_{3}$ & 1.00 & $1.27 *$ & - & - \\
\hline 4 times $\mathrm{O}_{3}$ & 1.00 & 1.63 & 5.21 & 5.14 \\
\hline $\mathrm{H}_{2} \mathrm{O}$ & 1.08 & 2.20 & 4.68 & 7.35 \\
\hline
\end{tabular}

*-indicates a statistically significant difference, $\mathrm{P} \leq 0.05$ 
Percentage of spring wheat infested by aphids increased in all treatments of the experiment on 7 th of June. Nevertheless, the number of aphid infested plants was the lowest and statistically significantly differed from the control in wheat treated with ozonated water. Thereby it should be noted that the highest average number of aphids per infested plant was detected in ozonated water treated spring wheat. Although this indicator was not statistically significantly different from the control.

The prevalence of aphids in spring wheat was found to decrease in all treatments of the experiment on 13th of June. The lowest percentage of plants infested by aphids (24\%) was detected in spring wheat treated with ozonated water, although the difference from the control was not statistically significant. The average number of pests per infested plant was observed the lowest in spring wheat treated with ozonated water, while it was statistically insignificant comparing to control.

Haplothrips aculeatus and Limothrips denticornis are the most commonly detected in spring cereal fields in Lithuania. The percentage of plants infested by thrips and the average number of pests per infested plant are presented in Table 4.

Table 4. Percentage of plants infested by thrips and average number of pests per infested plant in different treatments of the experiment during the monitoring of spring wheat crop.

\begin{tabular}{|c|c|c|c|c|}
\hline \multicolumn{5}{|c|}{ Percentage of plants infested by pests $(P)$} \\
\hline \multirow{2}{*}{ Treatments } & \multicolumn{4}{|c|}{ Dates of collection of samples } \\
\hline & $24 / 05$ & $31 / 05$ & 07/06 & $13 / 06$ \\
\hline Control & 1.33 & 0.00 & 5.33 & 4.67 \\
\hline 2 times $\mathrm{O}_{3}$ & 0.00 & 0.00 & - & - \\
\hline 4 times $\mathrm{O}_{3}$ & 0.00 & 0.67 & 3.33 & 1.33 \\
\hline $\mathrm{H}_{2} \mathrm{O}$ & 1.00 & 0.00 & 0.00 & 4.67 \\
\hline \multicolumn{5}{|c|}{ Average number of pests per infested plant $(K)$} \\
\hline \multirow{2}{*}{ Treatments } & \multicolumn{4}{|c|}{ Dates of collection of samples } \\
\hline & $24 / 05$ & $31 / 05$ & $07 / 06$ & $13 / 06$ \\
\hline Control & 0.67 & 0.00 & 1.83 & 0.67 \\
\hline 2 times $\mathrm{O}_{3}$ & 0.00 & 0.00 & - & - \\
\hline 4 times $\mathrm{O}_{3}$ & 0.00 & 0.33 & 0.67 & 0.33 \\
\hline $\mathrm{H}_{2} \mathrm{O}$ & 0.50 & 0.00 & 0.00 & 0.33 \\
\hline
\end{tabular}

*- indicates a statistically significant difference, $\mathrm{P} \leq 0.05$

First thrips specimens were observed in the control and in the water-treated spring wheat during the monitoring on 24th of May. On average 0.5 and 0.67 specimens were found per infested plant. Nevertheless, the results did not differ significantly comparing to the control.

$0.67 \%$ of plants infested by thrips were detected in ozonated water-treated wheats on 31st of May. An average number of thrips per infested plant was also recorded in the treatment with ozonated water application and reached 0.33 of specimen. There were no statistically significant differences comparing to the control.

$5.33 \%$ of plants infested by thrips were found on 7th of June in the control treatment, with an average of 1.83 specimen per infested plant. Meanwhile, $3.33 \%$ of thrips-infested plants were detected in spring wheat sprayed with ozonized water, and the average number of thrips per infested plant reached 0.67 of specimen. No thrips were found in water-treated spring wheat. However, the obtained results had no statistically significant differences comparing to the control.

$1.33 \%$ of thrips-infested plants were found in spring wheat sprayed with ozonized water on 13th of June. Although this result was 3.5 times lower comparing with control, it did not differ statistically significantly. The average number of thrips per infested plant in ozonated water treated spring wheat was lower comparing with the control, nonetheless statistically significant difference was not defined.

\section{CONCLUSIONS}

1. The application of ozonated water in spring wheat crop inhibited the spread of powdery mildew (Blumeria graminis), although not always statistically significantly.

2. The impact of ozonated water on the spread of tan spot disease (Pyrenophora tritici repentis) in spring wheat crop was diverse. A decrease of the spread of tan spot disease in spring wheat treated with ozonized water was only observed at the end of the observation period, although the obtained results were not statistically significant.

3. The application of ozonated water in spring wheat crop, in most cases statistically significantly reduced the spread of aphids.

4. Although the number of thrips in spring wheat crop was low in treatments where ozonated water was applied, a tendency of pests' prevalence reduction was observed.

\section{REFERENCES}

1. Glowac, M., Rees D. 2016. The practicality of using ozone with fruit and vegetables. Journal of the Science of Food and Agriculture, Vol. 96(14), pp. 4637-4643 https://doi.org/10.1002/jsfa.7763

2. Glowacz M., Colgan R., Rees D. 2015. The use of ozone to extend the shelf-life and maintain quality of fresh produce. Journal of the Science of Food and Agriculture, Vol. 95(4), pp. 662-671. https://doi.org/10.1002/jsfa.6776 
3. Guzel-Seydim Z., Greene A., Seydim, A. 2004. Use of ozone in the food industry. LWT - Food Science and Technology, Vol. 37(4), pp. 453-460 https://doi.org/10.1016/j.1wt.2003.10.014

4. Han Q., Gao H., Chen H., Fang X., Wu W. 2017. Precooling and ozone treatments affects postharvest quality of black mulberry (Morus nigra) fruits. Food Chemistry, Vol. 221, pp. 1947-1953 https://doi.org/10.1016/j.foodchem.2016.11.152

5. Hollingsworth R., Armstrong J. 2005. Potential of temperature, controlled atmospheres, and ozone fumigation to control thrips and mealybugs on ornamental plants for export. Journal of Economic Entomology, Vol. 98(2), pp. $289-298$. https://doi.org/10.1093/jee/98.2.289

6. Holopainen J., Kainulainen P., Oksanen J. 1997. Growth and reproduction of aphids and levels of free amino acids in Scots pine and Norway spruce in an open-air fumigation with ozone. Global Change Biology, Vol. 3(2), pp. 139-147 https://doi.org/10.1046/j.1365-2486.1997.00067.x

7. Hua-Li X., Yang B., Raza H., Hu-jun W., Lu-Mei P., Mi-Na N., Xiao-Yan C., Yi W., Yong-Cai L. 2018. Detection of NEO in muskmelon fruits inoculated with Fusarium sulphureum and its control by postharvest ozone treatment. Food Chemistry, Vol. 254, pp. 193-200. https://doi.org/10.1016/j.foodchem.2018.01.149

8. Mokslo ir enciklopedijų leidybos centras. 2015. Ozonas. Chemijos enciklopedija, pp. 515-516. (In Lithuanian)

9. Pazarlar S., Cetinkaya N., Bor M., Ozdemir F. 2017. Ozone triggers different defence mechanisms against powdery mildew (Blumeria graminis DC. Speer f. sp. tritici) in susceptible and resistant wheat genotypes. Functional Plant Biology, Vol. 44(10), pp. 1016-1028 https://doi.org/10.1071/FP17038

10. Violini G. 1995. Ozone and Plant Pathogens: An Overview. Rivista Di Patologia Vegetale, 5(3), 113-130. Retrieved from http://www.jstor.org/stable/42555772

11. Žemès ūkio augalų kenkejjai, ligos ir jų apskaita: mokslinis metodinis leidinys / Valstybinė augalų apsaugos tarnyba, Lietuvos žemdirbystès institutas, Lietuvos sodininkystès ir daržininkystės institutas; [sudarè Jonas Šurkus, Irena Gaurilčikienė]. Akademija (Kèdainių r.): Lietuvos žemdirbystės institutas, 2002. 345 p. (In Lithuanian) 